\title{
An Integrated Framework for Assessing the Value of Community-Based Prevention: A Report of the Institute of Medicine
}

\author{
Nicolaas P. Pronk, PhD; Lyla M. Hernandez, MPH; Robert S. Lawrence, MD
}

Suggested citation for this article: Pronk NP, Hernandez LM, Lawrence RS. An Integrated Framework for Assessing the Value of Community-Based Prevention: A Report of the Institute of Medicine. Prev Chronic Dis 2013;10:120323. DOI: http://dx.doi.org/10.5888/pcd10.120323 通.

Since the early 190os, the major causes of illness and death in the United States have changed from infectious disease to chronic disease. Recognition is growing that nonclinical community- and population-based prevention has a large role in improving the public's health and well-being. Health risks such as obesity, tobacco use, and low levels of physical activity are the result of a set of complex, interrelated factors that are difficult to untangle and identify. Health behaviors are important (1), but the importance of such factors as the physical, psychosocial, socioeconomic, and legal environments cannot be overstated (2). Community-based, nonclinical prevention policies and wellness strategies account for as much as $80 \%$ of the overall health of a population (3), yet assessing the value of community-based prevention remains challenging and complex. How should the value of community-based prevention be assessed? What should be measured? What should be counted, for whom, over what time period, and how?

To address this issue, the California Endowment, the de Beaumont Foundation, the W.K. Kellogg Foundation, and the Robert Wood Johnson Foundation asked the Institute of Medicine (IOM) to develop a framework for assessing the value of community-based prevention. The charge to the committee included examining the sources of data needed and available for valuing; the concepts of generalization, scaling up, and program sustainability; and the national and state policy implications of implementing such a framework. We provide a brief overview of the report, "An Integrated Framework for Assessing the Value of Community-Based Prevention" developed by the Committee on Valuing Community-Based, Non-Clinical Prevention Programs (4).

\section{The Concept of Value}

Valuing community-based prevention is a complex process. The value of an intervention depends on one's point of view. For example, public health workers may support a needle-exchange program to reduce HIV transmission rates because evidence indicates its effectiveness (5). However, others in the community may be opposed because they view such a program as facilitating illegal drug use. The trade-offs between benefits and harms are valued differently by each group.

Another important concept in assessing value is the decision of whether or not to monetize the effect of the prevention program. Monetization is not always easily accomplished. Expressing the time resource of a paid worker in dollars is simple, but reflecting the dollar value of increased social cohesion in a community may be impossible.

\section{The Difficulty in Assessing the Value of Community-Based Prevention}

The importance of investing resources to avoid further deterioration of health once a person is ill is generally accepted. It is much more challenging to persuade people to invest resources in programs and services designed to change individual, community, and systems actions before someone becomes sick. Benefits of certain interventions may not apply to the entire population, yet costs are shared and immediate while the benefits are often deferred. Prioritizing among interventions may also be challenging, and disagreements over the relative urgency for 1 program choice over another may hinder decision-making processes. 
Community means different things to different people in different contexts and can be defined in many ways. For the purpose of the report, the committee defined it as any group of people who share geographic space, interests, goals, or history. A community offers diverse potential targets for prevention and is often conceived of as an encompassing, proximal, and comprehensive structure that provides opportunities and resources that shape people's lifestyle (6). A community also provides opportunity for pooling resources that help support initiatives designed to directly or indirectly promote, adopt, and sustain health, regardless whether such initiatives are in the health sector or not.

\section{The Domains of Value}

The committee identified 3 domains of value (Box). The first domain, health (at both the individual and group levels), is an important outcome of interest in community-based prevention. Elements such as education, income, green space, crime, social support, and workplace safety were grouped into the second domain, community well-being. Success in community health promotion programs has been related to processes that reflect elements such as leadership, skill building, and civic participation (7). These elements were categorized as community process.

\section{A Proposed New Framework}

The committee concluded that a framework for assessing the value of community-based prevention should meet at least 3 criteria:

1. It should account for benefits and harms in 3 domains: health, community well-being, and community process.

2. It should consider the resources used and compare benefits and harms with those resources.

3. It should be sensitive to differences among communities and take those into account in valuing community-based prevention.

Eight existing frameworks were reviewed to determine their relevance for gathering and processing information to aid intelligent decision making (because a framework for assessing value is embedded within a decision-making context) and, more specifically, whether any of the frameworks met all 3 criteria; none did. Thus, a new framework was created (Figure); it proposes a comprehensive consideration of benefits and harms in the context of health, community wellbeing, and community process. It also proposes a comprehensive consideration of the resources used to plan, implement, and evaluate prevention interventions.

\section{Box. The 3 Value Domains and Examples of Elements and Possible Measures for Assessing the Value for Community-Based Disease Prevention}

\begin{tabular}{|l|l|}
\hline $\begin{array}{l}\text { Example of } \\
\text { Element }\end{array}$ & \multicolumn{1}{|c|}{ Possible Measure } \\
\hline \multicolumn{2}{|l|}{ Health } \\
\hline Overall & $\begin{array}{l}\text { Quality-adjusted life year or } \\
\text { health-adjusted life expectancy }\end{array}$ \\
\hline Quality of life & Self-reported health status \\
\hline Perceived health & \multicolumn{2}{|l|}{} \\
\hline Physical & Deaths \\
\hline $\begin{array}{l}\text { Mortality } \\
\text { cause) }\end{array}$ & $\begin{array}{l}\text { Rates of conditions or diseases of } \\
\text { interest, unhealthy days }\end{array}$ \\
\hline Morbidity & $\begin{array}{l}\text { Level of activities of daily living, } \\
\text { exercise }\end{array}$ \\
\hline $\begin{array}{l}\text { Functional } \\
\text { capacity }\end{array}$ & $\begin{array}{l}\text { Rates of injury } \\
\text { schools, libraries, housing }\end{array}$ \\
\hline Injuries & $\begin{array}{l}\text { Cognitive Abilities Screening } \\
\text { Instrument (adult), Dementia } \\
\text { Rating Scale (adult), Differential } \\
\text { Abilities Scale (children) }\end{array}$ \\
\hline Mental & $\begin{array}{l}\text { Self-reported mentally unhealthy } \\
\text { days }\end{array}$ \\
\hline $\begin{array}{l}\text { Cognition } \\
\text { (depression, } \\
\text { anxiety, stress) }\end{array}$ & $\begin{array}{l}\text { Self-reported mentally healthy } \\
\text { days }\end{array}$ \\
\hline $\begin{array}{l}\text { Perceived well- } \\
\text { being }\end{array}$ & Rates of suicide \\
\hline Suicide & \begin{tabular}{l} 
Bundt environmenty Well-Being \\
\hline Land use
\end{tabular} \\
\hline
\end{tabular}




\begin{tabular}{|c|c|}
\hline $\begin{array}{l}\text { Example of } \\
\text { Element }\end{array}$ & Possible Measure \\
\hline Transportation & $\begin{array}{l}\text { Number of sidewalks for walking, } \\
\text { bike paths, buses, metro/trains, } \\
\text { automobiles }\end{array}$ \\
\hline $\begin{array}{l}\text { Building quality } \\
\text { (indoor air) }\end{array}$ & $\begin{array}{l}\text { Levels of pollutants (eg, radon, } \\
\text { tobacco smoke, chemicals) }\end{array}$ \\
\hline Food systems & $\begin{array}{l}\text { Grocery stores with healthy } \\
\text { choices, farmers' markets }\end{array}$ \\
\hline \multicolumn{2}{|c|}{ Natural physical environment } \\
\hline Green space & $\begin{array}{l}\text { Parks, preserved open spaces, } \\
\text { beauty }\end{array}$ \\
\hline \multicolumn{2}{|c|}{ Social and economic environments } \\
\hline $\begin{array}{l}\text { Social support } \\
\text { and social } \\
\text { networks }\end{array}$ & $\begin{array}{l}\text { Number, type, frequency of } \\
\text { contact }\end{array}$ \\
\hline Social cohesion & Trust, respect \\
\hline Education & Number and quality of schools \\
\hline Resources & $\begin{array}{l}\text { Books, computers, play } \\
\text { equipment, class size }\end{array}$ \\
\hline Achievement & $\begin{array}{l}\text { 3rd-grade reading level, high } \\
\text { school and college graduation } \\
\text { rates }\end{array}$ \\
\hline Health literacy & Change in level of health literacy \\
\hline Employment & Employment/unemployment rate \\
\hline $\begin{array}{l}\text { Safe work } \\
\text { places }\end{array}$ & $\begin{array}{l}\text { Physical environment and job } \\
\text { effort }\end{array}$ \\
\hline Stress & $\begin{array}{l}\text { Job demand vs control, job effort } \\
\text { vs rewards }\end{array}$ \\
\hline Income & $\begin{array}{l}\text { Wages, Supplemental Nutrition } \\
\text { Assistance Program (SNAP) (food } \\
\text { stamps) }\end{array}$ \\
\hline $\begin{array}{l}\text { Crime and } \\
\text { safety }\end{array}$ & Rates for various crimes \\
\hline $\begin{array}{l}\text { Access to health } \\
\text { care and health } \\
\text { insurance }\end{array}$ & $\begin{array}{l}\text { Number and type of health care } \\
\text { facilities, rate of uninsured }\end{array}$ \\
\hline \multicolumn{2}{|c|}{ Community Process } \\
\hline $\begin{array}{l}\text { Local leadership } \\
\text { development }\end{array}$ & $\begin{array}{l}\text { Elected leaders reflect community } \\
\text { diversity, number and type of } \\
\text { community activists }\end{array}$ \\
\hline Skill building & $\begin{array}{l}\text { Number and type of peer } \\
\text { counselors and community } \\
\text { organizers }\end{array}$ \\
\hline $\begin{array}{l}\text { Civic } \\
\text { engagement or } \\
\text { participation }\end{array}$ & $\begin{array}{l}\text { Voting rates, volunteering, } \\
\text { participation in clubs or other } \\
\text { local organizations }\end{array}$ \\
\hline $\begin{array}{l}\text { Community } \\
\text { mobilization }\end{array}$ & $\begin{array}{l}\text { Involvement in civic activities (eg, } \\
\text { town hall meetings) }\end{array}$ \\
\hline
\end{tabular}




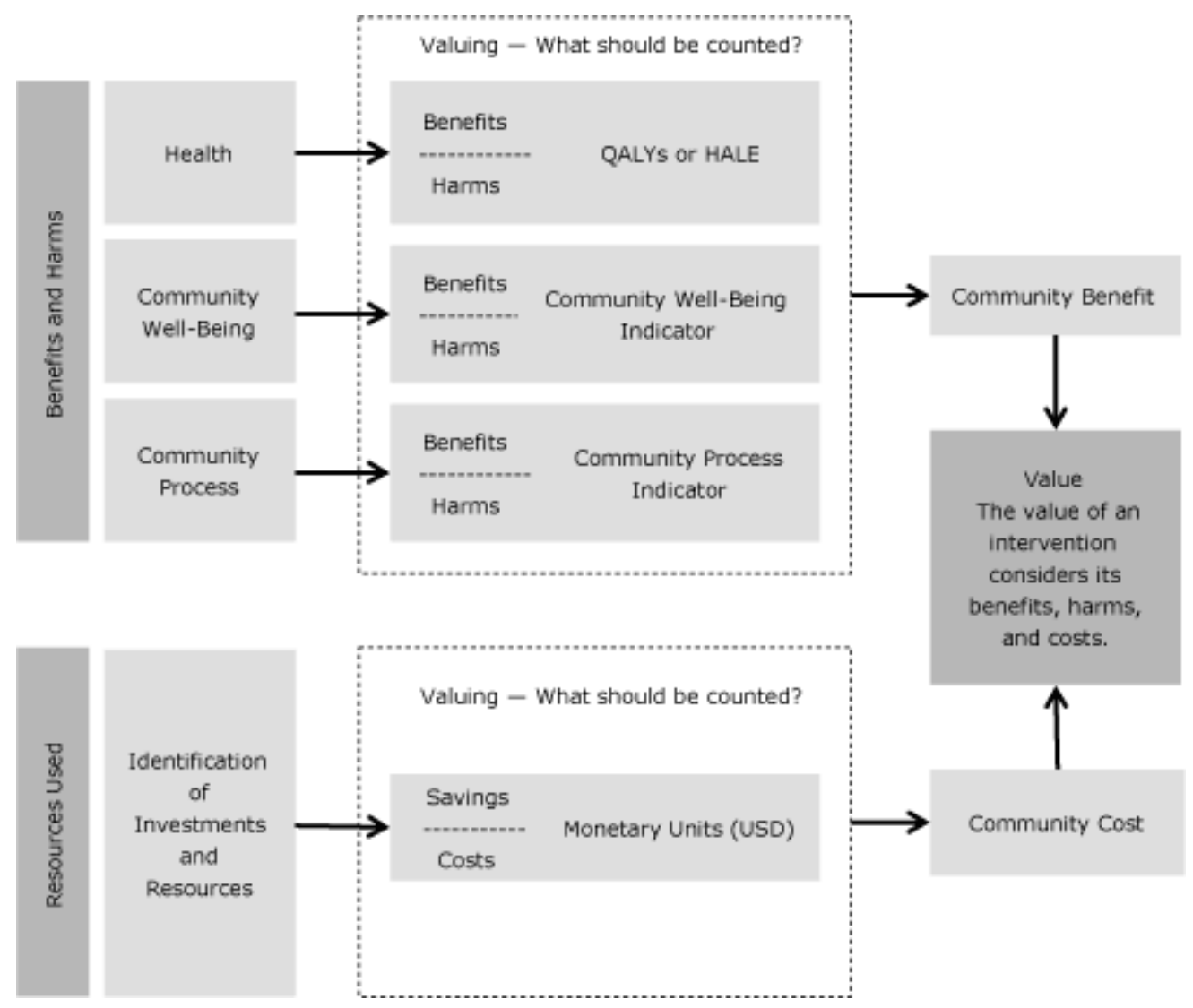

Figure. Framework for assessing the value of community-based prevention interventions, 2012. Abbreviations: QALYs, quality-adjusted life years; HALE, health-adjusted life expectancy. Reprinted with permission from the Institute of Medicine. [A text description of this figure is also available.]

The goals of the new framework are to 1) incorporate the full scope of benefits into the value of interventions, 2) emphasize that value requires a comparison of the benefits and harms of an intervention with the resources used for that intervention, 3) allow the characteristics and context of each community to be reflected in the valuation of community-based prevention, 4) promote the quantification of value in terms of projected or actual changes effected by the intervention, and 5) encourage the development of evidence to make understanding the effects of interventions easier and more reliable.

\section{Recommended Action}

Measures of health exist (eg, quality-adjusted life years, health-adjusted life expectancy) (8), but measures for the newly introduced domains of community well-being and community process are lacking. Identifying gaps in data sources and developing data sources to fill those gaps are priorities. So is the creation of a metric for community wellbeing and a metric for community process that could be combined with health measures into a summary indicator of community benefit. Furthermore, decision makers should ensure that elements included in the valuation process reflect the preferences of an inclusive range of stakeholders. A final recommendation reflects the need for transparency to optimize legitimacy of the process.

Value of a proposed community-based prevention intervention is affected by the possible conflict between health inequalities and aggregate health. The degree to which people are willing to trade increased inequality for aggregate improvement may vary significantly, and reasonable disagreement about how to weigh these 2 values may exist. Use of the proposed new framework can make the source for such disagreement more visible. Persistence of such disagreements may suggest a potential legitimacy problem for decision makers. The evidence used for valuation and estimates of the uncertainty of the results should be made public, and decision makers should consider making publicly available the rationales of their decisions.

The new framework is in its early stages, so its near-term effect on policy is likely limited. Expansion of its influence requires building consensus that the proposed domains - health, community well-being, and community process are all of value in community-based prevention. The data needed to measure tangible benefits adequately are often not 
available, and the measurement of less tangible benefits is not yet well developed. Good-quality cost data are also important $(9,10)$.

At this time, the committee considers it an important step to promote the use of the framework in the community setting. Although indicators of community well-being and community process are lacking, and so is a summary measure of community benefit, early use of the framework may be useful in identifying all relevant and important elements valued by a community. Those elements should be summarized in outcomes tables and linked to metrics when they are available. Elements that lack metrics should not be left out; rather, a metric should be created, and an attempt at valuing should be made. In addition, we need to validate the framework by showing repeatedly that it correctly distinguishes between interventions that improve value and those that do not. This process will almost certainly require refinement of the framework and expansion of the evidence base.

Although many challenges for comprehensive use of the proposed framework remain, it represents an important step toward realizing the elusive goal of appropriately and comprehensively valuing community-based disease prevention. Use of the framework by communities and decision makers will allow for refinement of the framework and strengthen its value.

\section{Acknowledgments}

The California Endowment, the de Beaumont Foundation, the W.K. Kellogg Foundation, and the Robert Wood Johnson Foundation sponsored the IOM report. Drs Pronk and Lawrence were members of the IOM study committee and Ms Hernandez was the study director. Views expressed in this commentary that are not directly identified as content in the report should be attributed to the authors and may not represent the views of the IOM. The authors have no conflicts of interest to declare and did not receive financial support for preparing this essay. The members of the Committee on Valuing Community-Based, Non-Clinical Prevention Programs are Robert S. Lawrence (chair), Johns Hopkins Bloomberg School of Public Health, Baltimore, Maryland; Kirsten Bibbins-Domingo, University of California, San Francisco, California; Laura K. Brennan, Transtria, LLC, St. Louis, Missouri; Norman Daniels, Harvard University, Cambridge, Massachusetts; Darrell J. Gaskin, Johns Hopkins Bloomberg School of Public Health, Baltimore, Maryland; Lawrence W. Green, University of California, San Francisco, California; Robert Haveman, University of Wisconsin-Madison, Madison, Wisconsin; Jennifer Jenson, Partnership for Prevention, Washington, DC; F. Javier Nieto, University of Wisconsin School of Medicine and Public Health, Madison, Wisconsin; Daniel Polsky, University of Pennsylvania, Philadelphia, Pennsylvania; Louise Potvin, University of Montréal, Montréal, Canada; Nicolaas P. Pronk, HealthPartners, Minneapolis, Minnesota; Louise B. Russell, Rutgers, The State University of New Jersey, New Brunswick, New Jersey; Steven M. Teutsch, Los Angeles County Department of Public Health, Los Angeles, California; and Chapin White, Center for Studying Health System Change, Washington, DC. Members of the IOM study staff are Lyla M. Hernandez, study director, Melissa French, associate program officer; Andrew Lemerise, research associate; Angela Martin, senior program assistant; Rose Marie Martinez, senior director, Board on Population Health and Public Health Practice.

\section{Author Information}

Corresponding Author: Nicolaas P. Pronk, PhD, HealthPartners, Health Promotion Department, 8170 33rd Ave S, Bloomington, MN 55425. Telephone: 952-967-6729. E-mail: nico.p.pronk@healthpartners.com. Dr Pronk is also affiliated with HealthPartners Institute for Education and Research, Minneapolis, Minnesota, and Harvard School of Public Health, Boston, Massachusetts.

Author Affiliations: Lyla M. Hernandez, Institute of Medicine, Washington, DC; Robert S. Lawrence, Johns Hopkins Bloomberg School of Public Health, Baltimore, Maryland.

\section{References}

1. Marmot MG, Wilkinson RG. Social determinants of health. Oxford (GB): Oxford University Press; 1999.

2. Institute of Medicine. For the public's health: investing in a healthier future. Washington (DC): The National Academies Press; 2012.

3. Booske BC, Athens JK, Kindig DA, Park H, Remington PL. Different perspectives to assigning weights to determinants of health. County Health Rankings working paper 2010.

http://uwphi.pophealth.wisc.edu/publications/other/different-perspectives-for-assigning-weights-todeterminants-of-health.pdf. Accessed December 6, 2012.

4. Institute of Medicine. An integrated framework for assessing the value of community-based prevention. Washington (DC): The National Academies Press; 2012. 
5. National Institutes of Health. Consensus development statement on interventions to prevent HIV risk behaviors. http://consensus.nih.gov/1997/1997PreventHIVRisk104html.htm. Accessed October 25, 2012.

6. McIntyre S, Ellaway A. Ecological approaches: rediscovering the role of the physical and social environment. In: Berkman L, Kawachi I, editors. Social epidemiology. New York (NY): Oxford University Press; 2000. p. 332-48.

7. Green LW. The theory of participation: a qualitative analysis of its expression in national and international health policies. Adv Health Ed Promot 1986;1:211-36.

8. Stiefel MC, Perla RJ, Zell BL. A healthy bottom line: healthy life expectancy as an outcome measure for health improvement efforts. Milbank Q 2010;88(1):30-53. CrossRef 图 PubMed 图

9. Gold MJ, Siegel L, Russell L, Weinstein M. Cost-effectiveness in health and medicine. New York (NY): Oxford University Press; 1996.

10. Polsky D, Glick H. Costing and cost analysis in randomized trials: caveat emptor. Pharmacoeconomics 2009;27 (3):179-88. CrossRef 通 PubMed 图

The opinions expressed by authors contributing to this journal do not necessarily reflect the opinions of the U.S. Department of Health and Human Services, the Public Health Service, the Centers for Disease Control and Prevention, or the authors' affiliated institutions.

The RIS file format is a text file containing bibliographic citations. These files are best suited for import into

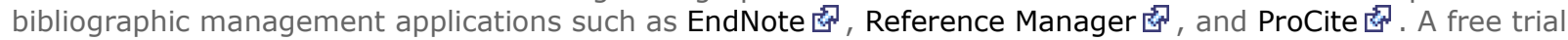
download is available at each application's web site.

For Questions About This Article Contact pcdeditor@cdc.gov

Page last reviewed: February 14, 2013

Page last updated: February 14, 2013

Content source: National Center for Chronic Disease Prevention and Health Promotion

Centers for Disease Control and Prevention 1600 Clifton Rd. Atlanta, GA 30333, USA

80o-CDC-INFO (800-232-4636) TTY: (888) 232-6348 - Contact CDC-INFO 